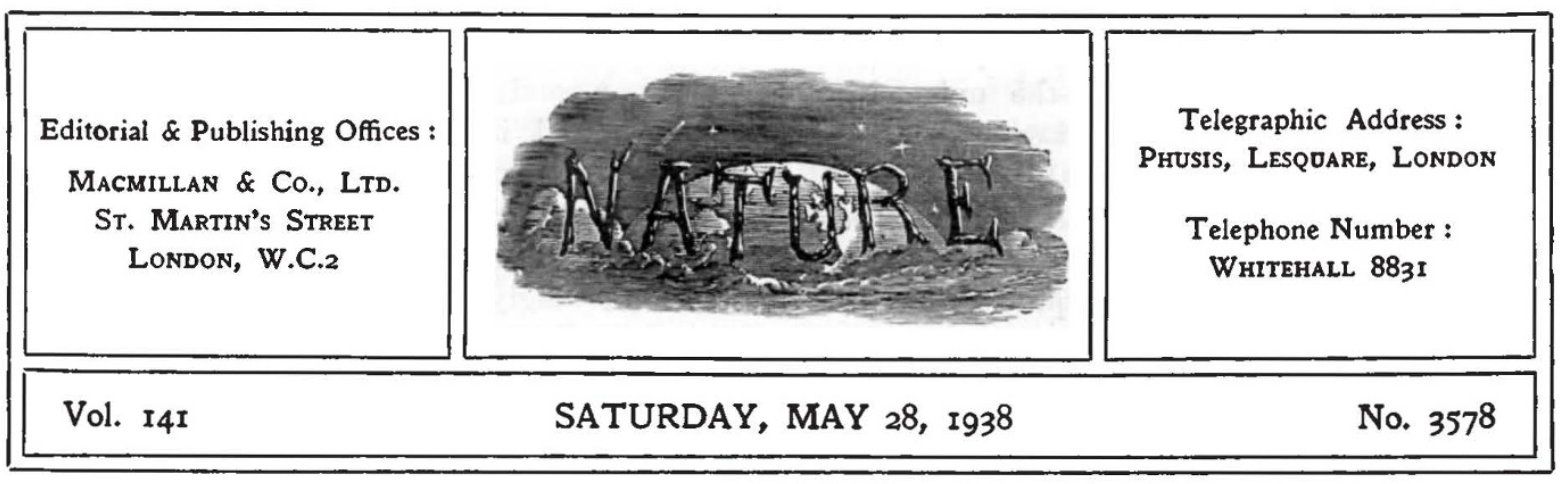

\title{
Scientific Research in International Affairs
}

"I the revolution of thought through which we are living, the profoundest and most disturbing element is the breakdown of that ethical system which, since the days of Constantine, has imposed upon European culture at least the semblance of moral unity." This remark made by the regius professor of Greek at Oxford in his inaugural lecture last year, was recalled by $\mathrm{Sir}$ Alfred Zimmern in his address at Chatham House last October on the decline of international standards. Recent events should convince the dullest mind of the extent to which international standards have deteriorated and the anarchy which threatens the repudiation of law and order in favour of brute force.

Sir Alfred Zimmern suggests that among the factors which have led to the deterioration of international standards the weakening of the Christian ethics and sanctions is significant; and there will be those ready to place upon science some of the responsibility for weakening such sanction and belief. However profound may have been the influence of science upon religious thought, the whole trend of scientific thought is in the direction of law and order, and in recent years there has been mutual recognition of the spiritual purposes of both science and religion if mankind is to regain control over events.

The present crisis places beyond question the supreme importance of some alliance of moral and scientific forces if the downfall of civilization is to be averted; and scientific workers in those centres where science still retains its freedom of thought and speech will be as united in their repudiation of the methods by which these are being repressed as they will be sincere in their sympathy for those distinguished men of science whose work and freedom are now threatened.
Outside the totalitarian States, differing political views are indeed largely determined not so much by matters of fact-though, of course, the extent to which particular holders of them have access to the facts may well vary enormously-but also, and even more important, by questions of judgment and values. It is precisely this point which was emphasized by Prof. M. Ginsberg in his thoughtful paper to the British Association at Nottingham last year. The present situation does indeed throw down yet a further challenge to the universities to play their part more fully in shaping and moulding a public opinion competent to sort out the issues and form sound judgments on questions of value as well as of fact.

In this respect, as Prof. Ginsberg has shown, the contribution of science is largely one of technique to resolve the difficulties in the way of clear, accurate and unprejudiced thought. This is, however, far from being the only contribution of science to the problem of international relations at the present time. Fully as significant is the question of painstaking and accurate research into the basic facts upon and by which decisions must be based, judgment determined and policy guided. Of the contribution which science could make in this field there could be no more admirable illustration than is offered by the study of the work of the Institute of Pacific Relations and its bearing on the problem of peaceful change, by H. F. Angus, which was issued for the Tenth International Studies Conference at Paris last June.

In this particular study, Mr. Angus is not concerned with practical issues, but he gives an impressive picture of the wide field for research which such questions as trade and tariffs, comparative standards of living, land utilization, population and migration, commercialization or 
industrialization present in China and in other Pacific countries. The basic research involved in the solution of such problems has its bearing on such particular questions as the Chinese claims for the rendition of Shanghai and other settlements and concessions, for tariff autonomy and the abolition of extra territoriality, and no one can read this study without realizing how imperfect as yet are the knowledge and facts available for the decision of many of the problems the solution of which is being attempted so unhappily by force at the present moment.

It is true, of course, that research in itself can accomplish very little in promoting the peaceful settlement of disputes, and the significance of the Institute of Pacific Relations lies in the use made of its research. By referring the conflict of beliefs to the arbitrament of research, it is possible to banish the acrimony which often embitters international relations through the conflict of different beliefs held by parties to the dispute. A politician may find it necessary, in order to retain his popularity, to reiterate the beliefs generally held by his supporters. It is a different matter for him, however, to repeat the same views in quarters in which repetition will appear merely as evidence of his ignorance or his insincerity.

Part of the achievement of the Institute of Pacific Relations has been to bring international controversy into the atmosphere of scientific research, but as yet it has made no determined effort to diffuse this atmosphere among the general public by making accurate information and its thoughtful interpretation widely available. There has, of course, been a great improvement in the position here in recent years. The extent to which careful analysis has been made in the scientific spirit of the facts which lie behind the demands of a nation for an alteration of the status quo is being made plain by the publications of the Institute of Pacific Relations, the Royal Institute of International Affairs and other such organizations. Though the field of research is still immense, much is being done and is already available as a basis for action if Governments and nations are prepared to use the results of such research.

It is here that we reach the crucial issue at the present. The degree to which force is being accepted as the means for one-sided redress of real or imagined grievances raises new and disturbing issues, and it becomes more and more difficult to deal justly even with the original matters in dispute. The indignation raised by Japan's campaign in China, for example, leads many to overlook the genuineness of many of her grievances and the sincerity of her point of view. Sir Alfred Zimmern's address indicates how grave has been the deterioration in this field and how imperative is the work of education and of promoting a social integration between countries and groups of centres which will give the existing organization for co-operation an opportunity to function.

It is still true that public opinion remains the decisive factor in determining the conduct of foreign affairs and international relations by any Government. The Press and broadcasting and educational policy are, under modern conditions, far more potent instruments than ever before by which a Government can influence public opinion. But none the less, even in the totalitarian State, a Government can rarely proceed far in advance of the point for which propaganda has prepared its supporters, and may easily on the other hand arouse feelings which carry it far beyond the point at which it intended to halt.

It is this situation, in which nationals of one country make little or no attempt to appreciate the point of view of those of another, and do not seek to understand the reasons for one another's prejudices, that constitutes one of the greatest obstacles to international progress and co-operation to-day. International agreements, whether between individual powers or collectively through the League of Nations, have little force unless there is some common standard and measure of understanding in the minds of the parties to them. To promote such understanding and standards is of vital importance. The real significance of the admirable non-political work of the League of Nations to-day in the field of health, the settlement of refugees, the protection of women and children, the suppression of slavery and the control of the trade in opium and other narcotic drugs, or its reconstruction work like that in Austria, Hungary, Greece or in China, now interrupted by the war, like the work of the International Labour Organization, lies not less in the direct contribution offered to the relief of human suffering and distress than in the extent to which it prepares the way for understanding and good will and co-operation in a wider field.

The history of international sanctions, as revealed in the important recent study by a group of members of the Royal Institute of International Affairs, does not indeed indicate the invalidity of sanctions. What it reveals is the dangerous loose- 
thinking in this subject, the widely differing standards of values and thought in different centres. It demonstrates beyond question that collective security can only function effectively when public opinion in the different countries has been educated out of its parochialism and brought to an appreciation of what is really involved in international relations in this new world, in which the forces that science has placed at our disposal have much power to build or to destroy.

Those responsible for this wise and well-balanced study were not concerned directly with the larger questions as to whether or no the attempt to establish a world order on the basis of international law should be continued. Their purpose was rather to discover how far the constitution of a system of sanctions for the enforcement of international legal obligations is a feasible proposi- tion. To this question they give no categorical answer. The book embodying the results of their investigation marshals the facts and analyses the experience so that others may be in a position to form their own conclusions. None the less, if the weaknesses and dangers of sanctions as hitherto applied are clearly expressed, the report puts the pregnant question whether, if the world lacks the spirit of courageous and self-sacrificing co-operation on which sanctions depend, any' alternative course is available whereby the calamity of war can be permanently averted. The whole trend of recent events reinforces these pleas for calm and courageous thinking, and for a moral basis for the wise and determined action which must be taken if the rich heritage of eivilization as we know it to-day is to be preserved from relapse into barbarism.

\section{The Fourth Estate}

Report on the British Press:

a Survey of its Current Operations and Problens, with special reference to National Newspapers and their Part in Public Affairs. Pp. ix +333 . (London: Political and Economic Planning, 1938.) 10s. $6 d$.

THERE could be no more appropriate time than the present for a searching examination and re-appraisal of the British Press. Over a large part of the globe, freedom of thought and of speech has disappeared; and in the countries where truth still survives, its free expression is being subjected to economic, political and social pressures never before known except in time of war. The continued freedom of the Press, once taken for granted, is by no means a certainty even in Great Britain, if the intolerable political stresses of the past two or three years are not eased soon.

Moreover, there are many in Great Britain, devoted to the cause of truth, who cannot regard the present-day freedom of the Press as an unmixed blessing. Dissatisfaction with the performance of the British Press is growing, almost as fast in Fleet Street as elsewhere. How satisfactorily does the Press inform its readers promptly, truthfully, fairly, of what is going on in the world? How seriously is it dominated by its commercial proprietors or by outside pressure-groups like the advertisers? Is it, in fact, living up to its high position as the Fourth Estate?
These are only a few of the scores of pertinent questions which the research workers of P E P (Political and Economic Planning) have sought to answer in their admirable report on the British Press, published after three years of effort. The report makes no claim to be exhaustive ; indeed, its authors found the utmost difficulty in assembling the material needed for what they have modestly described as a "preliminary analysis". Too often they have had to use one newspaper office as the source of their detailed information, although they should have had the co-operation of all.

Within its admitted limitations, their work is, however, beyond praise as a severely objective study of what is at the same time a great industry, a vital profession and a public utility of incalculable importance. The report is a rich storehouse of information on every conceivable aspect of British newspapers. It tells, in astonishing detail, how newspapers are produced, how they are financed, how the news is gathered. It takes the layman behind the scenes in newspaper offices on a night when some important event "breaks" after the first edition has gone to press. Considering the speed and pressure of daily newspaper production, it is one of the miracles of modern life that they should be as complete and as accurate as they are.

Yet this report is by no means a 'white-washing' document. It at least touches upon most of the shortcomings of the British Press and finds much 